\title{
Antibiotic susceptibility, antibacterial activity and characterisation of Enterococcus faecium strains isolated from breast milk
}

\author{
SERTAÇ ARGUN KIVANÇ ${ }^{1}$, MERIH KIVANÇ $^{2}$ and TÜLAY YIĞIT ${ }^{3}$ \\ ${ }^{1}$ Department of Ophthalmology, School of Medicine, Uludağ University, Görükle, 16059 Bursa; \\ ${ }^{2}$ Department of Microbiology, Faculty of Science; ${ }^{3}$ Institute of Science, Anadolu University, Eskişehir 26470, Turkey
}

Received July 14, 2015; Accepted May 18, 2016

DOI: $10.3892 / \mathrm{etm} .2016 .3545$

\begin{abstract}
Enterococci, which have useful biotechnological applications, produce bacteriocins, including those that exert anti-Listerial activity. The present study aimed to determine the antibiotic susceptibility patterns and antimicrobial activity of Enterococcus faecium strains isolated from human breast milk. The strains were identified using carbohydrate fermentation tests and ribotyping. Subsequently, the antibacterial activity of the isolates was investigated, and the quantities of lactic acid and hydrogen peroxide produced, and the proteolytic activity of E. faecium, were determined. In addition, biofilm formation by E. faecium strains was assessed. E. faecium strains exhibited antimicrobial activity against food-borne and clinical bacterial isolates. Furthermore, following $24 \mathrm{~h}$ incubation, the tested strains exhibited resistance to a $\mathrm{pH}$ range of 2.0-9.5 and tolerance of bile acid, lysozyme activity and phenol. Supernatants of the E. faecium TM13, TM15, TM17 and TM18 strains were shown to be effective against Listeria monocytogenes, and were also resistant to heat. Further studies are required in order to determine whether certain strains of E. faecium may be used for the development of novel antibacterial agents.
\end{abstract}

\section{Introduction}

Breast milk, which is commonly recommended for infants, is of considerable importance to the development of neonatal gut microflora $(1,2)$. Feeding pre-term infants with breast milk was shown to reduce the incidence of necrotising enterocolitis (1). Furthermore, infants gained a rapid tolerance of enteral nutrition (1). Breast milk protects against infection and promotes long-term metabolic health, as well as reducing the occurrence of asthma and other atopic disorders (2). This effect may be

Correspondence to: Dr Sertaç Argun Kıvanç, Department of Ophthalmology, School of Medicine, Uludağ University, Görükle, 16059 Bursa, Turkey

E-mail: sakivanc@gmail.com

Key words: Enterococcus faecium, breast milk, probiotics, antibacterial activity, ocular surface the result of the combined action of breast milk components, including maternal immunoglobulins, immunocompetent cells and various antimicrobial compounds (3). As well as its benefits for an infant's health, breastfeeding has been shown to be beneficial for the health of the mother, including preventing complications in the breast such as blocked ducts, mastitis and breast abscesses, and also reducing the risk of Type II diabetes and breast and ovarian cancers $(4,5)$.

Enterococcus faecium, which is a commensal bacterial species in the gastrointestinal tracts of humans and animals, is a Gram-positive, facultative anaerobic cocci that occurs singly, in pairs or chains (6). In addition, E. faecium is commonly found in large numbers on vegetables and plants, and in soil, surface waters and dairy products (6). E. faecium produces bacteriocins that inhibit food-borne bacteria and intestinal pathogens $(2,7)$. Furthermore, various E. faecium strains have been used as efficient probiotics for humans $(1,2)$.

Enterococci have useful biotechnological and functional properties, including anti-Listerial activity $(7,8)$. The present study aimed to determine the antibiotic susceptibility patterns and antimicrobial activity of E. faecium strains isolated from human breast milk. Thus, the probiotic potential of E. faecium strains isolated from breast milk could be evaluated and the results may influence the development of novel antibacterials against clinical pathogens.

\section{Materials and methods}

Collection of breast milk. The present study analyzed isolates derived from breast milk samples obtained by a student for their Master of Science Thesis in 2005. The isolate samples that had been stored in $20 \%$ glycerol at $-86^{\circ} \mathrm{C}$ were activated by culturing in M17A broth for $24 \mathrm{~h}$.

Isolation and identification of bacteria. Breast milk samples were cultured anaerobically on MRS and M17 agar plates at $37^{\circ} \mathrm{C}$ for $48 \mathrm{~h}$ in order to isolate lactic acid bacteria. Subsequently, the isolates were examined under a microscope for cell morphological and Gram-staining analyses. In addition, the isolates were tested for oxidase and catalase activities. Sugar fermentation patterns of the isolates were determined using a API 20 STREP system (bioMérieux, Inc., Durham, NC, USA), according to the manufacturer's protocol. Isolates were examined for $\mathrm{CO}_{2}$ production from glucose, 
and growth at various temperatures $\left(4,15\right.$ and $\left.45^{\circ} \mathrm{C}\right)$, and $\mathrm{pH}$ values ( $\mathrm{pH} 3.9-9.6)$ were assessed. Ammonia production from arginine was analyzed and growth under various $\mathrm{NaCl}$ concentrations $(6,7.5$ and $10 \%)$ was investigated, according to previous studies $(9,10)$.

Isolates were identified using an automated ribotyping system. Specifically, EcoRI ribotyping was performed using an automated RiboPrinter ${ }^{\circledR}$ Microbial Characterisation System (DuPont, Wilmington, DE, USA), according to the manufacturer's protocol. Ribotype patterns were compared to patterns stored in the RiboPrinter ${ }^{\circledR}$ database. An isolate was identified when its ribotype pattern had a similarity of $\geq 0.86$ with a DuPont Identification Library Code (DUP-IDs).

Detection of antibacterial activity. Antibacterial activity of the isolates was investigated using a well diffusion assay. Briefly, Mueller-Hinton Agar was poured into sterile petri dishes, solidified and dried in a laminar flow cabinet for $30 \mathrm{~min}$ at room temperature. Wells of $6 \mathrm{~mm}$ diameter were formed in the agar using a cork borer, which were subsequently filled with $15 \mu \mathrm{l}$ soft agar. Supernatants from Enterococcus cultures $\left[10^{8}\right.$ colony forming unit $\left.(\mathrm{CFU}) / \mathrm{ml}\right]$ were obtained via centrifugation at 2,500 x g for $5 \mathrm{~min}$. Samples were neutralized by the addition of $5 \mathrm{~N} \mathrm{NaOH}$ ( $\mathrm{pH} 5.5)$.

Neutralized supernatants were filter-sterilized using a $0.22 \mu \mathrm{m}$ filter membrane. Subsequently, $80 \mu 1$ neutralized supernatant was dispensed into the wells and the plates were overlaid with $8 \mathrm{ml}$ soft agar $(0.75 \%$ agar $)$ and seeded with $8 \mu \mathrm{l}$ test bacteria culture $\left(\sim 10^{7} \mathrm{CFU} / \mathrm{ml}\right.$ stationary-phase cells). The plates were incubated at $37^{\circ} \mathrm{C}$ for $24 \mathrm{~h}$, and were subsequently examined for zones of inhibition.

Production of gelatinase and haemolytic activity. Strains were cultured in $\mathrm{M} 17$ broth at $37^{\circ} \mathrm{C}$ for $18 \mathrm{~h}$ and transferred onto blood agar at a density of $10^{7} \mathrm{CFU} / \mathrm{ml}$. Blood agar plates were incubated at $18-24 \mathrm{~h}$ for $37^{\circ} \mathrm{C}$, after which haemolytic activity was recorded. Production of gelatinase was assessed using trypticase soy agar, supplemented with $1.5 \%$ skimmed milk. Plates were incubated for $18 \mathrm{~h}$ at $37^{\circ} \mathrm{C}$. Following incubation, a clear halo surrounding the colonies was considered positive, as described in a previous study (11).

pH and bile acid resistance. M17 broth containing $200 \mathrm{mM}$ $\mathrm{KCl} / \mathrm{HCl}$ and $100 \mathrm{mM}$ citric acid/200 $\mathrm{mM} \mathrm{Na}_{2} \mathrm{HPO}_{4}$, buffered at $\mathrm{pH}$ 1.0-2.0 and $\mathrm{pH}$ 3.0-6.5 respectively, was used to determine bacterial growth under various $\mathrm{pH}$ conditions. In order to assess resistance to bile acid, cultures $\left(10^{8} \mathrm{CFU} / \mathrm{ml}\right)$ were inoculated (1\%) into M17 broth with or without Oxgall (0.15 or $0.5 \%$ ), and incubated at $37^{\circ} \mathrm{C}$ for $24 \mathrm{~h}$, after which growth was assessed.

Resistance to phenol and lysozyme activity. The ability of the isolates to grow on phenol was investigated by inoculating (2\%) cultures into $10 \mathrm{ml} \mathrm{M17} \mathrm{broth} \mathrm{in} \mathrm{the} \mathrm{presence} \mathrm{or} \mathrm{absence}$ of $0.4 \%$ phenol. Growth of the cultures was then determined following incubation for $24 \mathrm{~h}$ at $37^{\circ} \mathrm{C}$. In order to assess the resistance of the isolates to lysozyme activity, E. faecium strains (1:50) were inoculated into $10 \mathrm{ml} \mathrm{M} 17$ broth with or without lysozyme (100 ppm). Tubes were incubated at $37^{\circ} \mathrm{C}$ for $24 \mathrm{~h}$, after which growth was assessed.
Biofilm-formation assays. Biofilm formation on polystyrene microtitre plates was quantified using a method developed by Heilmann et al (12). Briefly, $50 \mu$ l overnight cultures were transferred onto the microtitre plates. MRS without glucose basal medium was supplemented with glucose, fructose, sucrose and $2 \%$ lactose, and $200 \mu \mathrm{l}$ of this medium was subsequently transferred to each microplate. Microplates were incubated for $24 \mathrm{~h}$ at $37^{\circ} \mathrm{C}$, after which the optical density (OD) of the biofilm was measured at $570 \mathrm{~nm}$ using an Automated Spectrophotometer. Biofim formation was evaluated as weak, moderate or strong according to OD measurements, as described previously (13). Biofilm analyses were repeated three times in triplicate for each strain.

Lactic acid determination. Lactic-acid production was assessed in sterilized skimmed milk. Briefly, sterilized skimmed milk was inoculated at a rate of $2 / 100 \mathrm{ml}$ with active strains of E. faecium and acidity was assessed by performing a titration. Acidity is expressed as $\mathrm{mg} / \mathrm{ml}$ lactic acid, according to a previous study (14).

Proteolytic activity. Proteolytic activities of the cultures were determined spectrophotometrically, using a previously described method (15). This method detects free tyrosine and tryptophan liberated in the reaction mixture. In the present study, proteolytic activity was measured in triplicate. Results were calculated using a calibration curve obtained from dilutions of tyrosine in distilled water, as described previously (16), and are expressed as $\mu \mathrm{g} / \mathrm{ml}$ tyrosine.

Hydrogen peroxide $\left(\mathrm{H}_{2} \mathrm{O}_{2}\right)$. The level of $\mathrm{H}_{2} \mathrm{O}_{2}$ produced by the isolates was determined spectrophotometrically, according to a previous study (17). Briefly, measurements were obtained following a $24 \mathrm{~h}$ incubation period in skimmed milk, and production was monitored at OD350. $\mathrm{H}_{2} \mathrm{O}_{2}$ was quantified using a $\mathrm{H}_{2} \mathrm{O}_{2}$ standard curve, performed with concentrations ranging from $1-10 \mu \mathrm{g} / \mathrm{ml}$.

Effect of enzymes, $p H$ and heat on the antibacterial activity of E. faecium strains. Concentrated supernatants of E. faecium strains were treated with various enzymes, including catalase (5 $\mu \mathrm{g} / \mathrm{ml}), \alpha$-amylase $(1 \mathrm{mg} / \mathrm{ml})$, pepsin $(10 \mathrm{U} / \mathrm{mg})$, trypsin $(2 \mathrm{mg} / \mathrm{ml}), \alpha$-chymotrypsin $(5 \mathrm{mg} / \mathrm{ml})$, proteinase $\mathrm{K}(1 \mathrm{mg} / \mathrm{ml})$ and lysozyme $(1 \mathrm{mg} / \mathrm{ml})$. Each enzyme was dissolved in sterile $0.05 \mathrm{M}$ sodium phosphate buffer and added to the E. faecium supernatant to a final concentration of $1 \mathrm{mg} / \mathrm{ml}$. Following incubation at $37^{\circ} \mathrm{C}$ for $4 \mathrm{~h}$, the reaction mixtures were heated at $100^{\circ} \mathrm{C}$ for $10 \mathrm{~min}$ to inactivate the enzymes. In addition, the effect of heat on the antibacterial activity of the E. faecium strains was determined. Briefly, the supernatants of the E. faecium strains were heated at $121^{\circ} \mathrm{C}$ for $20 \mathrm{~min}$, and the inhibitory activity against Enterococcus faecalis, L. monocytogenes 1 and Proteus vulgaris was subsequently determined using the well diffusion method. Experiments were performed in duplicate, using the untreated supernatant as a control.

Antibiotic susceptibility assay. Susceptibility of the E. faecium strains to ciprofloxacin $(30 \mu \mathrm{g})$, gentamicin $(120 \mu \mathrm{g})$, netilmicin sulfate $(10 \mu \mathrm{g})$, penicillin $\mathrm{G}(10 \mathrm{U})$, vancomycin $(30 \mu \mathrm{g})$ and cefaclor (30 $\mu \mathrm{g}$; all Oxoid, Ltd., Basingstoke, UK) was 


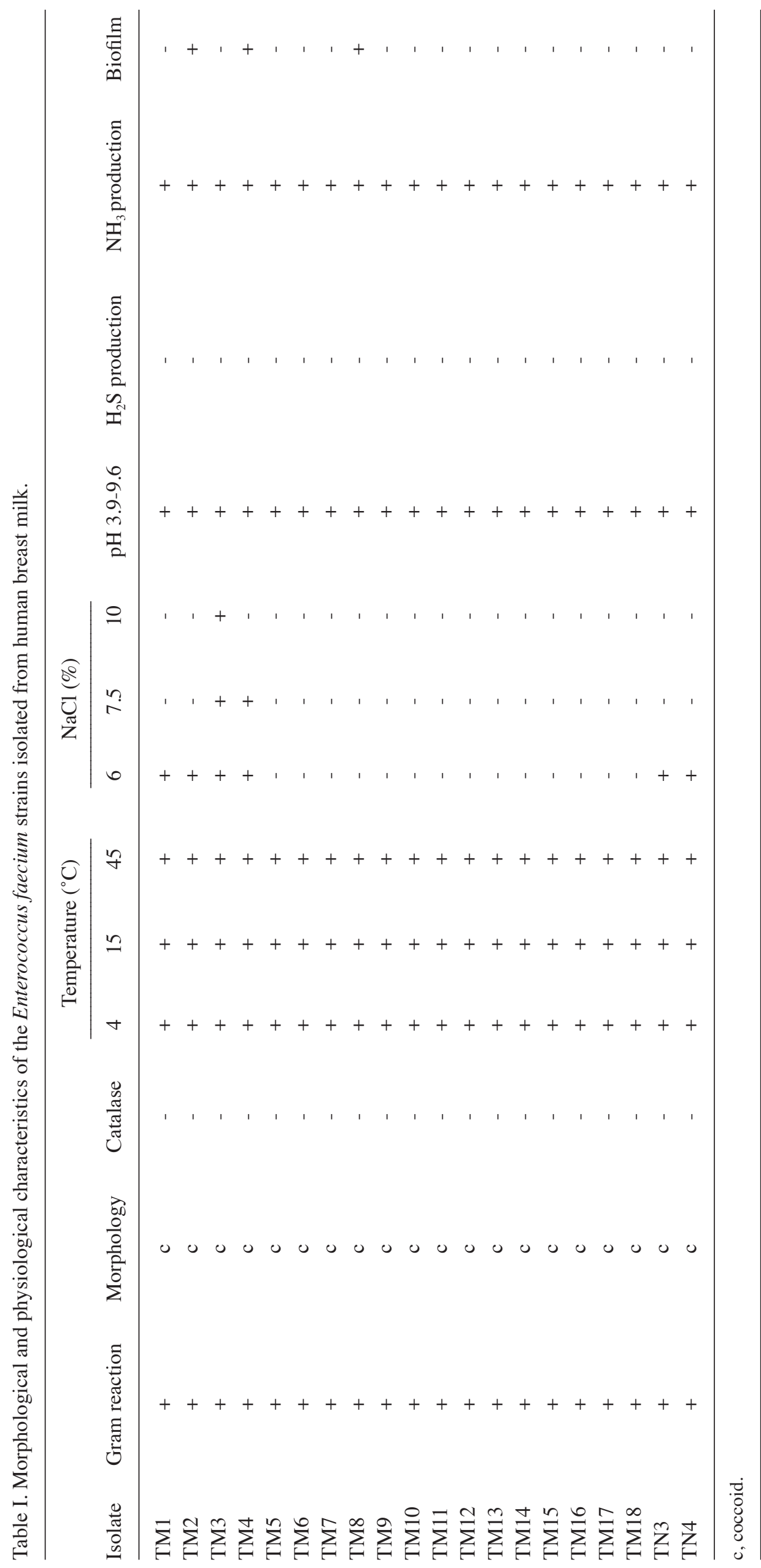


determined using the Kirby-Bauer Disk Diffusion method, as previously described (18). Susceptibility or resistance of the Enterococcus strains was determined according to the guidelines outlined by the Clinical and Laboratory Standards Institute (18).

\section{Results}

Identification of breast milk isolates. A total of 20 isolates were cultured from the breast milk sample, and identified using various phenotypic and genotypic tests. The results of cell morphological analyses, and the growth of the isolates at various temperatures and salinity, are presented in Table I. All isolates were Gram-positive, catalase-negative and oxidase-negative. Sugar fermentation tests were performed using the API ID 32 STREP system. According to the phenotypic tests, the strains were identified as E. faecium, which was confirmed by the automated EcoRI ribotyping results (Fig. 1). EcoRI ribotyping differentiated the isolates into two distinct ribotypes, with similarities ranging from 0.89-0.96. The two distinct ribotypes belonged to two DUP-IDs: DUP-6225, which was classified as Lineage I, and DUP-6227, which was classified as Lineage II.

Antibacterial activity of the isolates. Antibacterial activities of the isolates against various test strains are presented in Table II. Bacillus cereus, Escherichia coli, Klebsiella pneumoniae, Salmonella enterica, Salmonella typhimurium and Pseudomonas aeruginosa were not inhibited by E. faecium. However, the majority of E. faecium isolates were able to inhibit the growth of $P$. vulgaris, E. faecalis, L. monocytogenes 1, Lactococcus lactis, Lactobacillus plantarum, Leuconostoc paramesenteroides, Lactobacillus bulgaricus and Lactobacillus buchneri. A few of the E. faecium isolates exhibited inhibitory effects against L. monocytogenes, L. monocytogenes 2 and $S$. aureus. Of these, the E. faecium TM13, TM15, TM17, TM18 and TN3 strains exhibited the strongest antibacterial activity against the tested bacteria (Table II). Therefore, these strains were used for further analyses.

Production of gelatinase and haemolytic activity. The E. faecium TM4, TM13, TM15, TM17, TM18 and TN3 strains did not exhibit haemolytic activity. In addition, no gelatinase activity was detected in these strains (Table III).

Resistance of isolates to $\mathrm{pH}$, bile acid, lysozyme activity and phenol and biofilm formation. E. faecium strains exhibited a tolerance to a pH range of 2.0-9.6 (Table I). None of the test strains were able to survive at $\mathrm{pH} 1.0$ (Table III). Resistance to bile acid ( 0.15 and $0.5 \%$ Oxgall) was observed in all tested isolates exposed for $24 \mathrm{~h}$. Similarly, resistance to lysozyme activity was detected in all the isolates tested. Growth of E. faecium strains in the presence of phenol $(0.4 \%)$ at $37^{\circ} \mathrm{C}$ for $24 \mathrm{~h}$ was not observed (Table III). Biofilm formation was not observed in all tested strains, with the exception of three strains (Table I). These strains produced a weak biofilm, according to OD measurements.

Lactic acid and $\mathrm{H}_{2} \mathrm{O}_{2}$ production. In the present study, the E. faecium strains isolated from human breast milk were

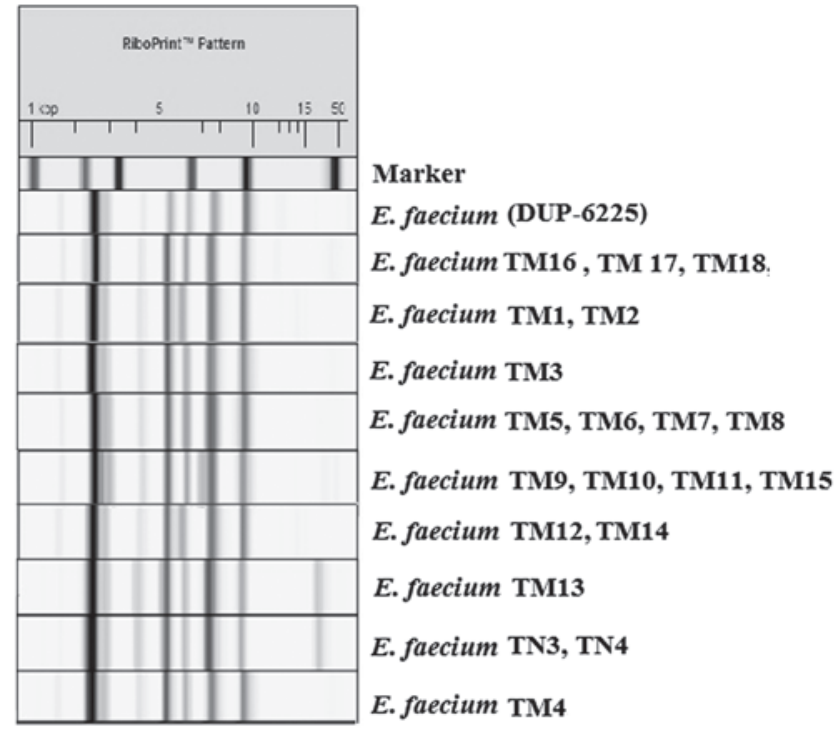

Figure 1. Ribotyping profiles of Enterococcus faecium isolates from human breast milk and standard (DUP-6225).

slow acid producers; after $24 \mathrm{~h}$ of growth, the $\mathrm{pH}$ values of the skimmed milk ranged from 4.2-5.5 (data not shown). The amount of lactic acid produced by E. faecium strains ranged from $12.49-16.59 \mathrm{mg} / \mathrm{ml}$ (Table IV). The production of $\mathrm{H}_{2} \mathrm{O}_{2}$ by E. faecium strains is presented in Table IV. The amount of $\mathrm{H}_{2} \mathrm{O}_{2}$ produced by lactic acid bacteria ranged from 2.17-1.09 $\mu \mathrm{g} / \mathrm{ml}$. The highest amount of $\mathrm{H}_{2} \mathrm{O}_{2}$ production was observed for E. faecium TN3.

Proteolytic activity. Proteolytic activities of the isolated strains are presented in Table IV. The amount of tyrosine released by these bacteria ranged from $0.23-0.96 \mathrm{mg} / \mathrm{ml}$. These results suggest that the E. faecium strains exhibit low proteolytic activity.

Antibacterial activity of TM13, TM15, TM17, TM18 and TN3 strains. The antibacterial activities of the E. faecium TM13, TM15, TM17 and TM18 strains were not affected by treatment with $\alpha$-amylase, catalase, trypsin, $\alpha$-chymotrypsin nor lysozyme; however, proteinase $\mathrm{K}$ was able to affect the antibacterial activity of all strains (Table V). Antibacterial activity of the E. faecium TN3 supernatant was affected by lysozyme, catalase and proteinase $\mathrm{K}$ treatment. The antibacterial activities of the supernatants of all E. faecium strains were retained following heating at $121^{\circ} \mathrm{C}$ for $5 \mathrm{~min}$ (Table V).

Antibiotic susceptibility profiles. E. faecium strains were resistant to ciprofloxacin, netilmicin sulfate and cefaclor; thus a multiresistant antibiotic profile was observed (Table VI). In addition, the E.faecium TM13, TM15, TM17, TM18 and TN3 strains were sensitive to vancomycin (Table VI). Only two of the 20 strains, TM1 and TM2, were resistant to all tested antibiotics.

\section{Discussion}

The present study isolated bacteria from human breast milk and identified them using conventional tests and an 


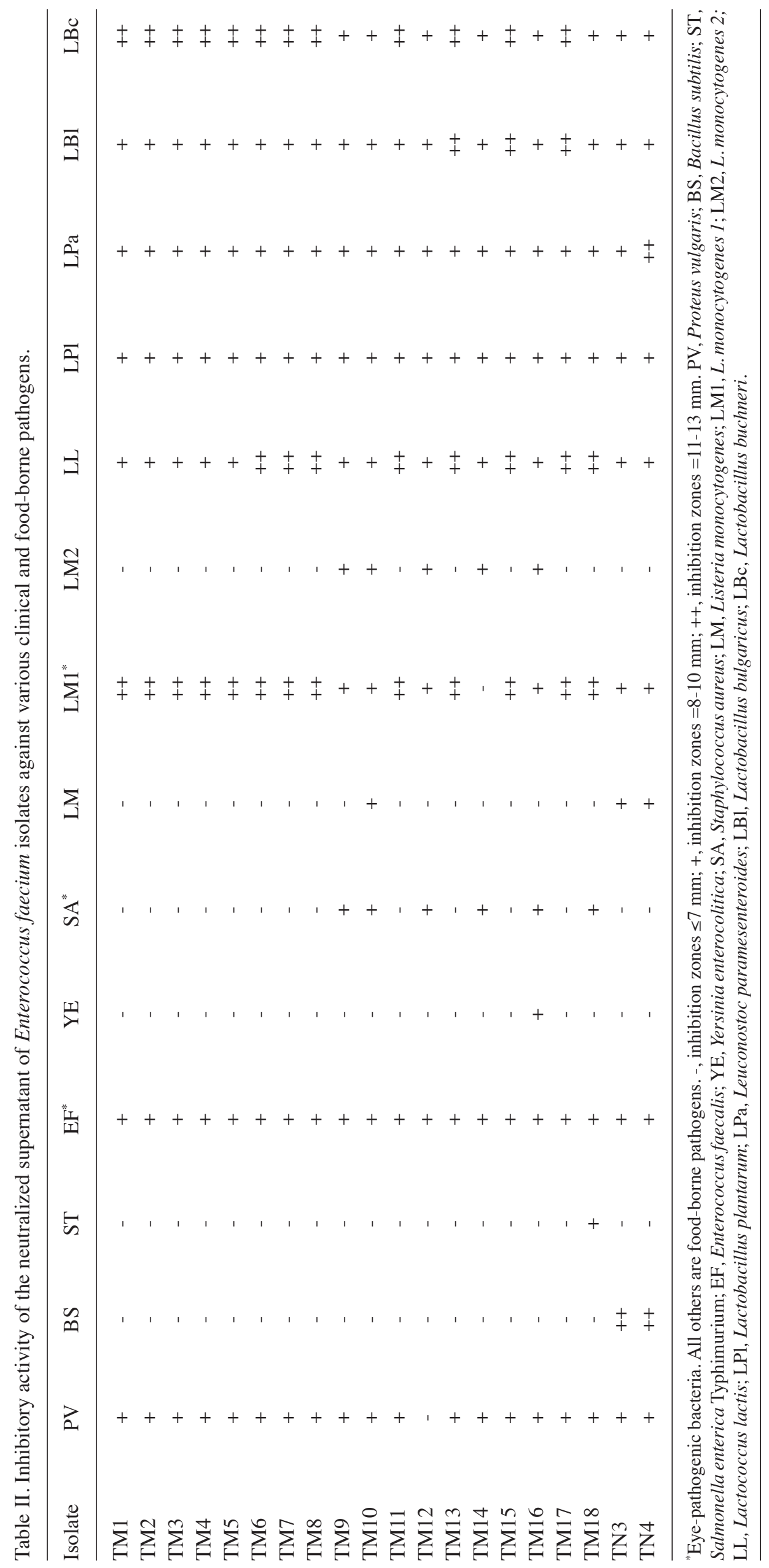


Table III. Acid and phenol tolerance, resistance to bile acid, and haemolytic and gelatinase activities of Enterococcus faecium strains isolated from human breast milk.

\begin{tabular}{|c|c|c|c|c|c|c|c|c|}
\hline \multirow[b]{2}{*}{ Isolate } & \multicolumn{3}{|c|}{ Acid tolerance } & \multirow{2}{*}{$\begin{array}{c}\text { Phenol } \\
\text { tolerance }\end{array}$} & \multirow{2}{*}{$\begin{array}{c}\text { Gelatinase } \\
\text { activity }\end{array}$} & \multirow{2}{*}{$\begin{array}{c}\text { Haemolytic } \\
\text { activity }\end{array}$} & \multirow{2}{*}{$\begin{array}{c}\text { Resistance to } \\
\text { bile acid }\end{array}$} & \multirow{2}{*}{$\begin{array}{c}\text { Resistance to } \\
\text { lysozyme }\end{array}$} \\
\hline & pH 1 & pH 2 & pH 3 & & & & & \\
\hline TM4 & - & + & + & - & - & - & + & + \\
\hline TM13 & - & ++ & ++ & - & - & - & + & + \\
\hline TM15 & - & ++ & ++ & - & - & - & + & + \\
\hline TM17 & - & + & + & - & - & - & + & + \\
\hline TM18 & - & ++ & ++ & - & - & - & + & + \\
\hline TN3 & - & ++ & ++ & - & - & - & + & + \\
\hline
\end{tabular}

-, no bacterial growth; +, bacterial growth was observed; ++, good bacterial growth was observed.

automated RiboPrinter ${ }^{\circledR}$ Microbial Characterisation System. According to phenotypic and genotypic characterisation tests, the isolates from the breast milk were all Gram-positive, non-spore-forming, catalase- and oxidase-negative, facultative anaerobic cocci identified as E. faecium. These isolates were able to grow at pH 9.6. E. faecium TM13, TM15, TM17 and TM18 strains grew poorly or not at all in the presence of $6.0 \% \mathrm{NaCl}$; this is inconsistent with a previous study in which E. faecium isolates survived in $6.5 \% \mathrm{NaCl}$ (19).

Martín et al (20) reported that Lactobacillus gasseri and E. faecium are the most commonly isolated microorganisms from human breast milk. In the present study, ribotyping and phenotypic identification methods suggested that the isolates were E.faecium. Furthermore, the isolates were differentiated into two distinct ribotypes using the Automated RiboPrinter ${ }^{\circledR}$.

The present study investigated the antibacterial activity of the supernatants of the E. faecium strains isolated from human breast milk. The E. faecium strains were able to inhibit $P$. vulgaris, E. faecalis, L. monocytogenes 1, L. lactis, L. plantarum, L. paramesenteroides, L. bulgaricus and L. buchneri. In particular, L. monocytogenes 1 was sensitive to all E. faecium strains, with the exception of TM14. L. monocytogenes 1 is an ocular surface isolate and so inhibition of this isolate by E. faecium may have important clinical applications. L. monocytogenes may cause ocular infections, including conjunctivitis, keratitis, chorioretinitis and endophthalmitis, that may lead to blindness. Furthermore, L. monocytogenes has been shown to cause a serious food-borne disease with a high mortality rate $(21,22)$.

Antimicrobial activity of E. faecium has previously been investigated $(7,23,24)$. The main cause of inhibitory activity may be associated with antibacterial peptides, namely bacteriocins (23). Kang and Lee (23) reported that the supernatant of E. faecium strains exhibited inhibitory activity against L. monocytogenes. Typically, Gram-negative bacteria are not susceptible to the supernatant of E. faecium; however, in the present study, $P$. vulgaris was sensitive to the E. faecium strains.

Haemolysin is an important enterococcal virulence factor (19). However, haemolytic activity was not observed for the E. faecium strains isolated from breast milk in the present study. In addition, no gelatinase activity was observed
Table IV. Lactic acid and $\mathrm{H}_{2} \mathrm{O}_{2}$ production by, and proteolytic activity of, Enterococcus faecium strains.

\begin{tabular}{lccc}
\hline Isolate & $\begin{array}{c}\text { Lactic } \\
\text { acid }(\mathrm{mg} / \mathrm{ml})\end{array}$ & $\begin{array}{c}\text { Proteolytic } \\
\text { activity } \\
(\text { Tyrosine } \mathrm{mg} / \mathrm{ml})\end{array}$ & $\begin{array}{c}\mathrm{H}_{2} \mathrm{O}_{2} \\
(\mu \mathrm{g} / \mathrm{ml})\end{array}$ \\
\hline TM13 & $14.33 \pm 0.04$ & $0.35 \pm 0.03$ & $1.24 \pm 0.02$ \\
TM15 & $16.59 \pm 0.04$ & $0.23 \pm 0.00$ & $1.31 \pm 0.04$ \\
TM17 & $13.33 \pm 0.00$ & $0.67 \pm 0.01$ & $1.09 \pm 0.02$ \\
TM18 & $12.49 \pm 0.01$ & $0.96 \pm 0.16$ & $1.30 \pm 0.00$ \\
TN3 & $13.88 \pm 0.01$ & $0.77 \pm 0.03$ & $2.17 \pm 0.11$ \\
\hline
\end{tabular}

$\mathrm{H}_{2} \mathrm{O}_{2}$, hydrogen peroxide.

for the E.faecium strains, which was consistent with previous studies $(25,26)$.

Lactic acid production by the E. faecium strains was low; whereas the $\mathrm{pH}$ of the growth medium was relatively high. In a previous study, enterococci derived from cheese exhibited a poor acidifying ability; only a slight decrease in the $\mathrm{pH}$ $(<5.0)$ of milk was observed following incubation for $24 \mathrm{~h}$ at $37^{\circ} \mathrm{C}(27)$. Conversely, an acidifying potential was demonstrated for E. faecium strains isolated from bovine milk; the $\mathrm{pH}$ of MRS broth was lowered to $~ 3.85-4.05$ following incubation for $48 \mathrm{~h}$ (26). In the present study, the Enterococci isolates were resistant to bile acid following exposure for $24 \mathrm{~h}$, which is consistent with a previous study (28). This resistance may be due to the inactivation of various bile components by $\beta$-glucuronidase activity.

In the presence of $0.4 \%$ phenol, E. faecium strains did not grow following incubation for $24 \mathrm{~h}$. In a previous study, Enterococci strains exhibited a high resistance to phenol (28). Lysozyme promotes the hydrolysis of the bacterial cell (29). The E.faecium strains isolated in the present study exhibited resistance to lysozyme-mediated hydrolysis, which is consistent with a previous study (28).

Of the 20 E. faecium strains isolated from breast milk in the present study, only two were biofilm producers, although these exhibited only weak biofilm-producing abilities. These 
Table V. Effect of enzymes or heat on the antibacterial activity of the Enterococcus faecium strains isolated from breast milk.

Heating at Isolate Filtrate Catalase Trypsin $\quad \alpha$-Chymotrypsin Lysozyme $\quad \alpha$-Amylase Proteinase $\mathrm{K} \quad 121^{\circ} \mathrm{C}$ for 20 min

\begin{tabular}{|c|c|c|c|c|c|c|c|c|}
\hline \multicolumn{9}{|c|}{ TM13 } \\
\hline $\mathrm{EF}$ & + & - & - & - & - & - & - & + \\
\hline PV & + & - & - & - & - & - & - & + \\
\hline LM & + & + & + & + & + & + & - & + \\
\hline \multicolumn{9}{|c|}{ TM15 } \\
\hline $\mathrm{EF}$ & + & - & - & - & - & - & - & + \\
\hline PV & + & - & - & - & - & - & - & + \\
\hline LM & + & + & + & + & + & + & - & + \\
\hline \multicolumn{9}{|c|}{ TM17 } \\
\hline $\mathrm{EF}$ & + & - & - & - & - & - & - & + \\
\hline PV & + & - & - & - & - & - & - & + \\
\hline LM & + & + & + & + & + & + & - & + \\
\hline \multicolumn{9}{|c|}{ TM18 } \\
\hline EF & + & - & - & - & - & - & - & + \\
\hline PV & + & - & - & - & - & - & - & + \\
\hline LM & + & + & + & + & + & + & - & + \\
\hline \multicolumn{9}{|l|}{ TN3 } \\
\hline $\mathrm{EF}$ & + & - & - & - & - & - & - & + \\
\hline PV & + & - & - & - & - & - & - & + \\
\hline LM & + & - & + & + & - & + & - & + \\
\hline
\end{tabular}

EF, Enterococcus faecalis; PV, Proteus vulgaris; LM, Listeria monocytogenes.

Table VI. Antibiotic susceptibility profiles of Enterococcus faecium strains from human breast milk.

\begin{tabular}{|c|c|c|c|c|c|c|}
\hline Isolate & $\begin{array}{l}\text { Vancomycin } \\
(30 \mu \mathrm{g})\end{array}$ & $\begin{array}{l}\text { Ciprofloxacin } \\
\quad(30 \mu \mathrm{g})\end{array}$ & $\begin{array}{l}\text { Penicillin } G \\
\quad(10 \mathrm{U})\end{array}$ & $\begin{array}{l}\text { Gentamicin } \\
(120 \mu \mathrm{g})\end{array}$ & $\begin{array}{l}\text { Netilmicin sulfate } \\
\qquad(10 \mu \mathrm{g})\end{array}$ & $\begin{array}{c}\text { Cefaclor } \\
(30 \mu \mathrm{g})\end{array}$ \\
\hline TM1 & $\mathrm{R}$ & $\mathrm{R}$ & $\mathrm{R}$ & $\mathrm{R}$ & $\mathrm{R}$ & $\mathrm{R}$ \\
\hline TM2 & $\mathrm{R}$ & $\mathrm{R}$ & $\mathrm{R}$ & $\mathrm{R}$ & $\mathrm{R}$ & $\mathrm{R}$ \\
\hline TM3 & $\mathrm{R}$ & $\mathrm{R}$ & I & $\mathrm{R}$ & $\mathrm{R}$ & $\mathrm{R}$ \\
\hline TM4 & $\mathrm{R}$ & $\mathrm{R}$ & $\mathrm{R}$ & I & $\mathrm{R}$ & I \\
\hline TM5 & $\mathrm{R}$ & $\mathrm{R}$ & $\mathrm{S}$ & $\mathrm{R}$ & $\mathrm{R}$ & $\mathrm{R}$ \\
\hline TM6 & S & I & $\mathrm{R}$ & $\mathrm{S}$ & $\mathrm{R}$ & $\mathrm{R}$ \\
\hline TM7 & $\mathrm{R}$ & $\mathrm{R}$ & $\mathrm{R}$ & $\mathrm{S}$ & $\mathrm{R}$ & I \\
\hline TM8 & $\mathrm{R}$ & $\mathrm{R}$ & $\mathrm{R}$ & $\mathrm{S}$ & I & $\mathrm{R}$ \\
\hline TM9 & $\mathrm{S}$ & $\mathrm{R}$ & $\mathrm{S}$ & I & $\mathrm{R}$ & $\mathrm{R}$ \\
\hline TM10 & $\mathrm{S}$ & $\mathrm{R}$ & $\mathrm{R}$ & $\mathrm{S}$ & $\mathrm{R}$ & $\mathrm{R}$ \\
\hline TM11 & $\mathrm{S}$ & $\mathrm{R}$ & I & $\mathrm{S}$ & $\mathrm{R}$ & $\mathrm{R}$ \\
\hline TM12 & $\mathrm{S}$ & I & $\mathrm{R}$ & $\mathrm{S}$ & $\mathrm{R}$ & $\mathrm{R}$ \\
\hline TM13 & $\mathrm{S}$ & $\mathrm{R}$ & $\mathrm{S}$ & $\mathrm{S}$ & I & $\mathrm{R}$ \\
\hline TM14 & $\mathrm{S}$ & $\mathrm{R}$ & $\mathrm{R}$ & $\mathrm{S}$ & $\mathrm{R}$ & $\mathrm{R}$ \\
\hline TM15 & $\mathrm{S}$ & $\mathrm{R}$ & I & $\mathrm{S}$ & $\mathrm{R}$ & I \\
\hline TM16 & $\mathrm{S}$ & $\mathrm{R}$ & $\mathrm{R}$ & $\mathrm{S}$ & $\mathrm{R}$ & $\mathrm{R}$ \\
\hline TM17 & S & $\mathrm{S}$ & $\mathrm{S}$ & $\mathrm{S}$ & $\mathrm{R}$ & S \\
\hline TM18 & $\mathrm{S}$ & $\mathrm{R}$ & $\mathrm{R}$ & $\mathrm{S}$ & $\mathrm{R}$ & $\mathrm{S}$ \\
\hline TN3 & $\mathrm{S}$ & $\mathrm{R}$ & $\mathrm{S}$ & I & I & I \\
\hline TN4 & $\mathrm{R}$ & I & $\mathrm{R}$ & $\mathrm{S}$ & $\mathrm{R}$ & $\mathrm{R}$ \\
\hline
\end{tabular}

$\mathrm{R}$, resistant; S, sensitive; I, intermediate. 
results are consistent with the findings for clinical isolates in a previous study (30).

The strains isolated in the present study may be considered as slow acid producers. These results are consistent with those reported by Arizcun et al (31). Furthermore, it has previously been shown that $E$. faecium exhibits weak proteolytic activity at $37^{\circ} \mathrm{C}$ after $72 \mathrm{~h}$ (32). Previous studies demonstrated that the majority of E. faecium isolates from dairy products exhibited weak proteolytic activities in milk $(27,33)$.

Enterococci, which are natural inhabitants of the gastrointestinal tract, are a type of lactic acid bacteria, thus $\mathrm{H}_{2} \mathrm{O}_{2}$ is the primary metabolite that may contribute to their antagonistic action (34). In the present study, the antimicrobial effect of the TN3 strain may have been associated with high $\mathrm{H}_{2} \mathrm{O}_{2}$ production. Notably, the antimicrobial activity of E. faecium TN3 was completely inhibited following treatment with proteinase $\mathrm{K}$, lysozyme, catalase and trypsin.

Antimicrobial activity of the E. faecium TM13, TM15, TM17 and TM18 supernatants was not affected by treatment with catalase, $\alpha$-amylase, $\alpha$-chymotrypsin, lysozyme nor trypsin. Conversely, the activities of all E. faecium supernatants were completely inhibited following treatment with proteinase $\mathrm{K}$, indicating that the antibacterial was proteinaceous in nature.

Bacteriocins produced by Enterococci are divided into two classes (35). Class II bacteriocins are small, cationic, hydrophobic and heat-stable peptides, and the strains in the present study, with the exception of the TN3 strain, exhibited properties that resembled the class II bacteriocins $(36,37)$. These findings are in agreement with a previous study (23). In addition, E. faecium has been shown to exhibit high acid resistance at pH 2.0 and 1.0 (28); however, in the present study, the E. faecium strains were susceptible to acid at $\mathrm{pH} 1.0$, which is consistent with a previous study (28).

The present study demonstrated that the ability of E. faecium strains to inhibit the growth of E. faecalis, $P$. vulgaris and L. monocytogenes was stable following heating for $20 \mathrm{~min}$ at $121^{\circ} \mathrm{C}$. This is inconsistent with a previous study, in which E. faecium isolates lost their inhibitory activity following heat treatment (26).

Enterococci are known to be resistant to antibiotics. A high degree of antibiotic resistance is associated with a combination of over-the-counter antibiotic sales and the inappropriate use of antibiotics. The most clinically relevant antibiotics include vancomycin and gentamicin, since these are able to treat infections caused by multi-drug resistant strains (7). In the present study, E. faecium strains were sensitive to vancomycin. However, antibiotic resistance may not explain the virulence of enterococci. On the other hand, a multiresistant antibiotic profile was observed in the present study. Strains of Enterococci resistant to multiple antibiotics have emerged in the last decade, and have demonstrated resistance to tetracycline, chloramphenicol and vancomycin (38). In addition, $85 \%$ of E. faecium clinical isolates were shown to be resistant to ciprofloxacin in Sweden (39), and a marked increase in high level resistance to gentamicin and vancomycin has previously been demonstrated (39).

Antibiotic resistance is a significant problem in the clinical setting, such that the discovery and development of novel antibiotics is required. Bacteriotherapy, in which bacteria are used against pathogenic bacterial strains in a host, has emerged as a novel area that may be useful in this endeavour (2). Bacteriocins produced by E. faecium may have useful clinical applications. The antibacterial activity of the supernatants of the E. faecium TM13, TM15, TM17 and TM18 strains were heat stable and sensitive to proteolysis. E. faecium TM13, TM15, TM17 and TM18 strains exhibited strong inhibitory activities against L. monocytogenes. In addition, E. faecium isolated from breast milk exhibited antibacterial effects against $L$. monocytogenes and $E$. faecalis isolated from human eyes. These isolates may be considered useful for the development of novel drugs against bacteria, and may have potential applications as probiotics and in the food industry.

\section{Acknowledgements}

The present study was supported by the Anadolu University Council of Research Project Fund (grant no. 41020).

\section{References}

1. Lindemann PC, Foshaugen I and Lindemann R: Characteristics of breast milk and serology of women donating breast milk to a milk bank. Arc Dis Child Fetal Neonatal Ed 8: F440-F441, 2004.

2. Martin R, Langa S, Reviriego C, Jiménez E, Marín ML, Olivares M, Boza J, Jiménez J, Fernández L, Xuas J and Rodríguez JM: The commensal microflora of human milk: New perspectives for food bacteriotherapy and probiotics. Trends Food Sci Technol 15: 121-127, 2004.

3. Saavedra JM: Clinical applications of probiotic agents. Am J Clin Nutr 73: 1147S-1151S, 2001.

4. Ip S, Chung M, Raman G, Chew P, Magula N, DeVine D, Trikalinos T and Lau J: Breastfeeding and maternal and infant health outcomes in developed countries. Evid Rep Technol Assess (Full Rep): 1-186, 2007.

5. Labbok M: Breastfeeding: A woman's reproductive right. Int J Gynaecol Obstet 94: 277-286, 2006.

6. Giraffa G: Functionality of enterococci in dairy products. Int J Food Microbiol 88: 215-222, 2003.

7. Foulquié Moreno MR, Sarantinopoulos P, Tsakalidou EL and De Vuyst L: The role and application of enterococci in food and health. Int J Food Microbiol 106: 1-24, 2006.

8. Cocolin L, Foschino R, Comi G and Fortina M: Description of the bacteriocins produced by two strains of Enterococcus faecium isolated from Italian goat milk. Food Microbiol 24: 752-758, 2007.

9. Schillinger U and Lucke FK: Identification of lactobacilli from meat and meat products. Food Microbiol 4: 199-208, 1987.

10. Stiles ME and Holzapfel WH: Lactic acid bacteria of foods and their current taxonomy. Int J Food Microbiol 36: 1-29, 1997.

11. Creti R, Imperi M, Bertuccini L, Fabretti F, Orefici G, Di Rosa R and Baldassarri L: Survey for virulence determinants among Enterococus faecalis isolated from different sources. J Med Microbiol 53: 13-20, 2004.

12. Stepanovic S, Vukovic D, Dakic I, Savić B and Svabic-Vlahovic M: A modified microtiter-plate test for quantification of staphylococcal biofilm formation. J Microbiol Methods 40: 175-179, 2000.

13. Christensen GD, Simpson WA, Younger JJ, Baddour LM Barrett FF, Melton DM and Beachey EH: Adherence of coagulase-negative staphylococci to plastic tissue culture plates: A quantitative model for the adherence of staphylococci to medical devices. J Clin Microbiol 22: 996-1006, 1985.

14. Demirci M and Gunduz H: Dairy Technology Handbook. Hasad Press, Turkey, p184, 1994.

15. Citti J, Sandine WE and Elliker PR: Some observations on the Hull method for measurement of proteolysis in milk. J Dairy Sci 46: 337, 1963.

16. RajagopalSNand Sandine WE: Fissociative growth and proteolysis of Streptococcus thermophilus and Lactobacillus bulgaricus in Skim Milk. J Dairy Sci 73: 894-899, 1990.

17. Patrick WA and Wagner HB: Determination of hydrogen peroxide in small concentrations. Anal Chem 21: 1279-1280, 1949. 
18. Clinical and Laboratory Standards Institute: Performance Standards for Antimimicrobial Susceptibility Testing; Twenty-Third Informational Supplement. CLSI, Wayne, PA, p199, 2013

19. Morandi S, Brasca M, Andrighetto C, Lombardi A and Lodi, R Technological and molecular characterization of enterococci isolated from north-west Italian dairy products. Int Dairy J 16 867-875, 2006.

20. Martín R, Langa S, Reviriego C, Jimínez E, Marín ML, Xaus J, Fernández L and Rodríguez JM: Human milk is a source of lactic acid bacteria for the infant gut. J Pediatr 143: 754-758, 2003.

21. Shoughy SS and Tabbara KF: Listeria monocytogenes endophthalmitis following keratoconjunctivitis. Clin Ophthalmol 8: 301-304, 2014

22. Gandhi M and Chikindas ML: Listeria: A foodborne pathogen that knows how to survive. Int J Food Microbiol 113: 1-15, 2007.

23. Kang JH and Lee MS: Characterization of a bacteriocin produced by Enterococcus faecium GM-1 isolated from an infant. J Appl Microbiol 98: 1169-1176, 2005.

24. Ohmomo S, Murata S, Katayama N, Nitisinprasart S, Kobayashi M, Nakajima T, Yajima $M$ and Nakanishi $K$ : Purification and some characteristics of enterocin ON-157, a bacteriocin produced by Enterococcus faecium NIAI 157. J App Microbiol 88: 81-89, 2000.

25. Mannu L, Paba A, Daga E, Comunian R, Zanetti S, Duprè I and Sechi LA: Comparison of the incidence of virulence determinants and antibiotic resistance between Enterococcus faecium strains of dairy, animal and clinical origin. Int J Food Microbiol 88: 291-304, 2003

26. Banwo K, Sanni A and Tan H: Technological properties and probiotic potential of Enterococcus faecium strains isolated from cow milk. J Appl Microbiol 114: 229-241, 2012.

27. Andrighetto C, Knijff E, Lombardi A, Torriani S, Vancanneyt M, Kersters K, Swings J and Dellaglio F: Phenotypic and genetic diversity of enterococci isolated from Italian cheeses. J Dairy Res 68: 303-316, 2001.

28. Vassos D, Bezirtzoglou EA, Voidarou C, Alexopoulos A and Maipa V: Biochemical and antimicrobial profile of Enterococcus faecium and E. faecalis isolated from traditional dairy products and infant intestinal microbiota. Microb Ecol Health Dis 21: 241-250, 2009.
29. Bottazzi V, Battistotti B, Bosi F, Corradini C and Dell'Acqua E: Effects of lysozyme on the thermophilous lactic ferments. 20th International Dairy Congress, Paris, pp535-536, 1978 (In French).

30. Di Rosa R, Creti R, Venditti M, D'Amelio R, Arciola CR, Montanaro L and Baldassarri L: Relationship between biofilm formation, the enterococcal surface protein (Esp) and gelatinase in clinical isolates of Enterococcus faecalis and Enterococcus faecium. FEMS Microbiol Lett 256: 145-150, 2006.

31. Arizcun C, Barcina $Y$ and Torre P: Identification and characterization of proteolytic activity of Enterococcus spp. isolated from milk and Roncal and Idiazábal cheese. Int J Food Microbiol 38: 17-24, 1997.

32. Suzzi G, Caruso M, Gardini F, Lombardi A, Vannini L, Guerzoni ME, Andrighetto C and Lanorte MT: A survey of the enterococci isolated from an artisanal Italian goat's cheese (semicotto caprino). J Appl Microbiol 89: 267-274, 2000.

33. Sarantinopoulos P, Kalantzopoulos G and Tsakalidou E: Effect of Enterococcus faecium on microbiological, physicochemical and sensory characteristics of Greek Feta cheese. Int J Food Microbiol 76: 93-105, 2002.

34. Juven BJ, Weisslowicz H and Harel S: Detection of hydrogen peroxide produced by meat lactic starter cultures. J Appl Bacteriol 65: 357-360, 1988.

35. Cotter PD, Hill C and Ross RP: Bacteriocins: Developing innate immunity for food. Nat Rev Microbiol 3: 777-788, 2005.

36. Perez R H, Zendo T and Sonomoto K: Novel bacteriocins from lactic acid bacteria (LAB): Various structures and applications. Microb Cell Fact 13 (Suppl 1): S3, 2014

37. Klaenhammer TR: Genetics of bacteriocins produced by lactic acid bacteria. FEMS Microbiol Rev 12: 39-85, 1993.

38. Yousif NM, Dawyndt P, Abriouel H, Wijaya A, Schillinger U, Vancanneyt M, Swings J, Dirar HA, Holzapfel WH and Franz CM: Molecular characterization, technological properties and safety aspects of enterococci from 'Hussuwa', an African fermented sorghum product. J Appl Microbiol 98: 216-228, 2005.

39. Billström H, Top J, Edlund C and Lund B: Frequent occurrence of multidrug-resistant CC17 Enterococcus faecium among clinical isolates in Sweden. J Appl Microbiol 108: 1810-1816, 2010. 